\title{
Orchard Floor Management Affects Peach Rooting
}

\author{
M.L Parker ${ }^{1}$, J. Hull, and R.L. Perry \\ Department of Horticulture, Michigan State University, East Lansing, MI 48824 \\ Additional index words. Prunus persica, Poa pratensis, Medicago sativa, Festuca rubra, Festuca arundinacea
}

\begin{abstract}
The root distribution of peach trees [Prunus persica (L.) Batsch cv. Redhaven/Halford] as affected by six orchard floor management treatments was evaluated after 3 years of growth. Two treatments were maintained vegetation-free and four had vegetative covers in the alleyway with a 1.2-m-wide herbicide strip in the tree row. The profile wall method was used to determine root distribution. Trees maintained vegetation-free with herbicide had the most roots. Trees in the vegetation-free plots, maintained with herbicide or cultivation, produced more roots $1.2 \mathrm{~m}$ from the tree than trees in the vegetative covers. The number of roots, $1.2 \mathrm{~m}$ from the tree, was lowest in the tall fescue treatment. The number of roots were higher in the Kentucky bluegrass (Poa pratensis L.) or alfalfa (Medicago sativa L.) than with tall fescue (Festuca arundinacea, Schreb.).
\end{abstract}

Michigan peach orchard floor management is primarily clean cultivation with cover crops planted in the fall, or vegetative covers with herbicide strips in the tree row. Several reviews have documented the effects of orchard floor management on tree growth and soil characteristics (Haynes, 1980; Hogue and Nielsen, 1987), but little has been reported about the effect on root growth and distribution (Atkinson, 1980).

Root distribution of various fruit crops differs in response to cultural management practices of tree spacing, fertility level, irrigation, and cultivar (Lyons and Krezdorn, 1962; Castle, 1980; Perry et al., 1983). Root distribution of orange (Citrus sinensis Osb.) trees was affected by tree density (Boswell et al., 1975; Castle, 1980). Nonirrigated peach trees had more roots than irrigated trees (Layne et al., 1986). Perry et al. (1983) reported large differences in the number of roots and root dry weight at various depths and lateral distances from the trunk of four Vitis cultivars.

A vegetation-free area around fruit trees had a significant effect on tree rooting (Atkinson and White, 1976). Apple (Malus domestica Borkh.) trees grown in grass had fewer roots and lower root weights than total vegetation-free treatments, which had the most roots. Ten-year-old apple trees maintained with a herbicide strip had higher root densities under the herbicide strip than under the vegetative alley. Tree roots under the vegetative alley grew deeper than those under the herbicide strip (Atkinson et al., 1977).

Glenn and Welker (1989) reported tall fescue sod resulted in reduced peach root length for roots $<1 \mathrm{~mm}$ in diameter compared to bare soil. Root length was reduced under both the sod and the 50$\mathrm{cm}$ vegetation-free zone between the sod and the tree. Both apple and peach trees that had not received supplemental irrigation rooted deeper than trees irrigated frequently (Beukes, 1984; Cripps, 1971; Layne et al., 1986; Richards and Cockroft, 1975).

Soil cultivation eliminated surface rooting while mulch on the soil surface encouraged rooting in the mulch and in the soil surface for apple, peach, and pear (Pyrus communis L.) (Beckenbach and Gourley, 1932; Cockroft and Wallbrink, 1966). The latter concluded that orchard floor management did not promote deeper rooting, but did affect surface rooting of peach trees.

Received for publication 6 Mar. 1992. Accepted for publication 27 Mar. 1993. We acknowledge the Michigan Agricultural Experiment Station for its support of this research. The cost of publishing this paper was defrayed in part by the payment of page charges. Under postal regulations, this paper therefore must hereby be marked advertisement solely to indicate this fact.

${ }^{1}$ Present address: Dept. of Horticultural Science, North Carolina State Univ., Raleigh, NC 276957609
This study was conducted to determine the impact of six orchard floor management systems on the root distribution of peach trees.

\section{Materials and Methods}

The research was conducted at the Michigan State Univ. Clarksville Horticultural Experiment Station in western Michigan on a Riddles sandy loam soil (moderately well-drained, typic Hapludalfs, fine-loamy, mixed, mesic). The soil A and B horizon interface was at a depth of $\approx 20 \mathrm{~cm}$. Six orchard floor management treatments were established and included two vegetation-free treatments and four vegetative covers with a 1.2 -m-wide herbicide strip in the tree row. Vegetative covers were seeded in Sept. 1985 in 6. 1-m square plots. Three peach trees ('Redhaven'/'Halford') were planted in Apr. 1986 in a tree row, oriented north to south, through the middle of each plot with trees spaced $2 \mathrm{~m}$ apart in the row and $6.2 \mathrm{~m}$ between rows. Treatments were: 1) Herbicidemaintained vegetation-free with herbicide; 2) Clean cultivationmaintained vegetation-free year-round with cultivation to the trunk of the tree; 3) 'Park' Kentucky bluegrass seeded at $100 \mathrm{~kg} \cdot \mathrm{ha}^{-1}$; 4) 'Wintergreen' chewings fescue (Festuca rubra L.) seeded at $\left.199 \mathrm{~kg} \cdot \mathrm{ha}^{-1} ; 5\right)$ 'Peak' alfalfa seeded at $22 \mathrm{~kg} \cdot \mathrm{ha}^{-1}$; and 6) 'Kentucky $31^{\prime}(\mathrm{K}-31)$ tall fescue seeded at $305 \mathrm{~kg} \cdot \mathrm{ha}^{-1}$.

Gramoxone (1,1'-dimethyl-4-4'-bypyridinium ion), a contact herbicide, was applied at $1.1 \mathrm{~kg} \cdot \mathrm{ha}^{-1}$ with $0.1 \% \mathrm{X}-77$ surfactant at $\approx 30$-day intervals during each growing season to control vegetation in the herbicide treatment plots and the vegetation-free strip in the tree row. The clean cultivation treatment was rototilled to a depth of $8 \mathrm{~cm}$ at 30- to 40-day intervals during the growing season to control vegetation throughout the entire plot.

Trees were pruned to an open center. The design was a randomized complete block with four replications. Data were collected from the middle tree in each plot.

The profile wall method described by Bohm (1979) was used to quantify the tree root system distribution. Trenches $\approx 70 \mathrm{~cm}$ wide and $1.8 \mathrm{~m}$ deep were dug in Oct. 1988, after the third growing season (Fig. 1). Two trenches were dug perpendicular to the tree row on the west side of the tree, from the tree trunk outward $1.2 \mathrm{~m}$ into the alley, $0.6 \mathrm{~m}$ from the tree trunk. A trench on the west side of the tree, $1.2 \mathrm{~m}$ from the tree, parallel to the tree row and transversing the two perpendicular trenches, provided two profilefaces, one $1.2 \mathrm{~m}$ from the tree and the other $1.9 \mathrm{~m}$ from the tree, both under the alley management treatment. Trench faces were prepared as described by Layne et al. (1986).

A $1.2 \times 1.0$-m grid frame divided by string into $20 \times 10-\mathrm{cm}$ 


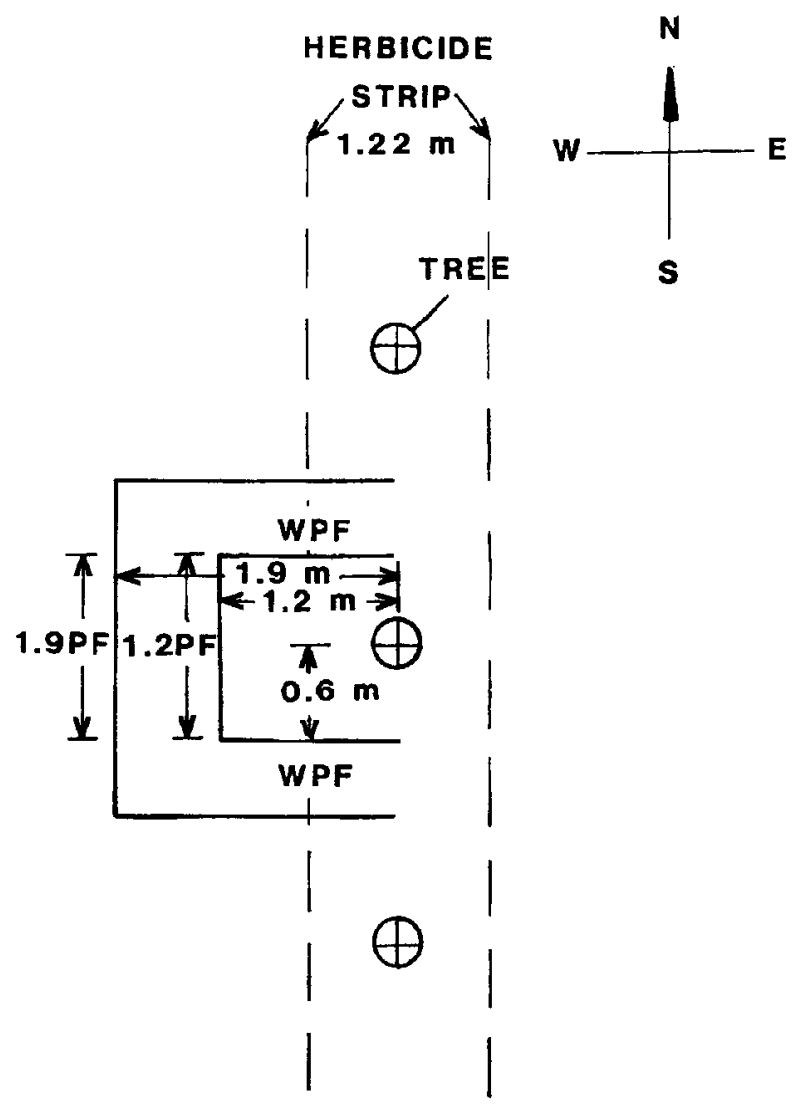

Fig. 1. Trench locations for peach tree root distribution study. $\mathrm{PF}=$ profile-face; $\mathrm{WPF}=$ west profile-face.

sections, was placed against the profile faces to assist in counting and mapping root distribution. Roots on each profile-face were counted, and recorded in one of two diameter categories-those 12 $\mathrm{mm}$ and those $>2 \mathrm{~mm}$. The west profile-face (WPF) data refers to total number of roots on the two trenches extending from the tree row outward $1.2 \mathrm{~m}$ into the alley (Fig. 1). The number of roots on the WPF were summed for the north and south faces of the trenches, $2.4 \times 1.0 \mathrm{~m}$ total area. The $1.2-\mathrm{m}$ profile-face $(1.2 \mathrm{PF})$ and the $1.9-\mathrm{m}$ profile-face $(1.9 \mathrm{PF}), 1.2$ and $1.9 \mathrm{~m}$, respectively, from the tree row, were individual profile-faces on the west side of the tree, $1.2 \times 1.0 \mathrm{~m}$ total area.

Soil bulk density and organic matter content were measured in the surface $8 \mathrm{~cm}$ of each orchard floor cover in Oct. 1988. Five soil cores (Blake, 1965) were taken from each replication, 20 per orchard floor cover, selected at random from both sides of the tree outside the herbicide strip. Soil bulk density was determined by oven dry weight/core volume (Blake, 1965) and soil organic matter was determined by percentage weight change after removal from a muffle furnace. Soil bulk density, which ranged from 1.41 to $1.55 \mathrm{~g} \cdot \mathrm{cm}^{-3}$, or soil organic matter, which ranged from $2.93 \%$ to $3.58 \%$ in the surface $8 \mathrm{~cm}$ of the soil, did not differ significantly among treatments.

Treatments did not differ significantly in the number of large roots; therefore, data were summed for small and large roots. Data presented are for total number of exposed roots on a $1-\mathrm{m}^{2}$ vertical plane. Data were analyzed for total number of roots at each of the three profile-face locations and in 40-cm columns and $20-\mathrm{cm}$ rows by analysis of variance (ANOVA), with mean separation by Duncan's multiple range test at the $P \leq 0.05$. The slope of the square root of the number of roots with depth was calculated for each tree. For each orchard floor management treatment, the average slope and standard deviations of the slopes were calculated. An ANOVA was also performed on the slopes of the square root of the number of roots for the orchard floor management treatments.

\section{Results and Discussion}

The orchard floor management treatments affected the total number of roots on all three profile faces (Table 1). On the WPF and the $1.2 \mathrm{PF}$, the number of roots of the peach trees did not differ significantly between the plots maintained vegetation-free by cultivation or herbicide. Trees in both vegetation-free treatments had more roots than any of the vegetative covers on the 1.2PF. Roots at the $1.2 \mathrm{PF}$ were directly beneath the orchard floor management system ( $60 \mathrm{~cm}$ beyond the herbicide strip). Reduced number of roots at the $1.2 \mathrm{PF}$ resulted from unequal competition of the vegetative covers. At the $1.9 \mathrm{PF}$, trees in the herbicide-treated plots had significantly more roots than those in any other treatment.

The WPF trench, which extended from the tree row $1.2 \mathrm{~m}$ into the alley, included a $60-\mathrm{cm}$ segment that was beneath the alley management treatment. This $60-\mathrm{cm}$ segment was outside of the herbicide strip that was maintained in all treatments, except for clean cultivation. The number of roots did not differ significantly under the herbicide strip (0-40 cm, Table 2). Significant differences in the number of roots would not be expected in this vegetation-free strip as there would be no vegetative cover interfering with the trees' root growth. Atkinson and White (1976) also found more apple roots in

Table 1. Numbers of peach tree roots per square meter at each profile-face location as affected by orchard floor management.

\begin{tabular}{llcr}
\hline & \multicolumn{3}{c}{ Profile-face } \\
\cline { 2 - 4 } Treatment & WPF $^{z}$ & $1.2 P^{y}$ & $1.9 P^{x}$ \\
\hline Herbicide & $192 \mathrm{a}^{\mathrm{w}}$ & $174 \mathrm{a}$ & $125 \mathrm{a}$ \\
Clean cultivation & $161 \mathrm{ab}$ & $159 \mathrm{a}$ & $44 \mathrm{~b}$ \\
Kentucky bluegrass & $157 \mathrm{a}-\mathrm{c}$ & $105 \mathrm{~b}$ & $37 \mathrm{~b}$ \\
Chewings fescue & $154 \mathrm{a}-\mathrm{c}$ & $75 \mathrm{bc}$ & $49 \mathrm{~b}$ \\
Alfalfa & $114 \mathrm{bc}$ & $85 \mathrm{~b}$ & $8 \mathrm{~b}$ \\
Tall fescue & $109 \mathrm{c}$ & $41 \mathrm{c}$ & $11 \mathrm{~b}$ \\
\hline zWPF $=$ West profile-face. & & &
\end{tabular}

$\overline{\mathrm{z}} \mathrm{WPF}=$ West profile-face.

${ }^{\mathrm{y}} 1.2 \mathrm{PF}=$ Profile-face $1.2 \mathrm{~m}$ from tree.

${ }^{\mathrm{x}} 1.9 \mathrm{PF}=$ Profile-face $1.9 \mathrm{~m}$ from tree.

"Means within columns separated by Duncan's multiple range test $(P \leq$ 0.05). Data shown are means of four observations.

Table 2. Number of peach tree roots per square meter on the west profileface (WPF) $0.6 \mathrm{~m}$ from the tree, perpendicular to the tree row as affected by distance from tree row and orchard floor management. Profile excavated to a depth of $1 \mathrm{~m}$.

\begin{tabular}{lccc}
\hline \hline \multirow{2}{*}{ Floor } & \multicolumn{3}{c}{ Distance from tree row $(\mathrm{cm})$} \\
\cline { 2 - 4 } management & $0-40$ & $40-80$ & $80-120$ \\
\hline \multirow{3}{*}{ Herbicide } & $234 \mathrm{a}^{2}$ & $215 \mathrm{a}$ & $125 \mathrm{a}$ \\
Clean cultivation & $180 \mathrm{a}$ & $178 \mathrm{ab}$ & $124 \mathrm{a}$ \\
Kentucky bluegrass & $233 \mathrm{a}$ & $169 \mathrm{a}-\mathrm{c}$ & $70 \mathrm{ab}$ \\
Chewings fescue & $207 \mathrm{a}$ & $151 \mathrm{~b}-\mathrm{d}$ & $103 \mathrm{a}$ \\
Alfalfa & $149 \mathrm{a}$ & $126 \mathrm{~cd}$ & $68 \mathrm{ab}$ \\
Tall fescue & $179 \mathrm{a}$ & $116 \mathrm{~d}$ & $31 \mathrm{~b}$ \\
\hline
\end{tabular}

${ }^{\bar{z}}$ Means within columns separated by Duncan's multiple range test $(P \leq$ $0.05)$. Data shown are means of four observations. 
the herbicide strip than in the vegetative alleys.

The 40- to $80-\mathrm{cm}$ column of the WPF included a transition zone between the herbicide strip and alley management treatment. Although $20 \mathrm{~cm}$ of this column was vegetation-free, the number of roots were still reduced significantly under all vegetative treatments, except the Kentucky bluegrass, compared to the herbicide treatment in this region. Trees in the vegetation-free treatments had more roots than trees in the alfalfa and tall fescue treatments. Trees grown in the Kentucky bluegrass also had significantly more roots than trees in tall fescue. The trees in the latter produced $47 \%$ fewer peach roots and those grown with chewings fescue produced $21 \%$ fewer roots than the trees in the herbicide treatment.

Root distribution 80 to $120 \mathrm{~cm}$ from the tree row was located completely under the alley management system. Trees grown in both vegetation-free treatments or chewings fescue had more roots than trees in tall fescue. Trees in tall fescue had 25\% as many roots as trees in the herbicide treatment. Glenn and Welker (1989) reported reduced peach tree root length under tall fescue sod and also in the transition zone from a vegetation-free area to the tall fescue sod.

Trees grown in the tall fescue and alfalfa also had fewer roots than trees in the vegetation-free areas or the Kentucky bluegrass in the surface $20 \mathrm{~cm}$ of the WPF (Table 3). These differences in the number of roots were present in the area from the tree row outward $1.2 \mathrm{~m}$ into the alley and included both the herbicide strip and alley management system. No significant treatment differences were present below the surface $20 \mathrm{~cm}$, although the trends were similar to those of the $0-$ to $20-\mathrm{cm}$ depth.

The 0 - to 20-cm depth of the 1.2-m WPF soil was also divided into three $40-\mathrm{cm}$ segments to determine if the number of roots differed beneath the orchard floor management treatments (Table 4). The 0- to 40-cm segment included the herbicide strip, and there were no significant treatment differences. The $40-$ to $80-\mathrm{cm}$ segment was a transition zone between the herbicide strip and the alley management treatment. Here, trees in the vegetation-free and the Kentucky bluegrass plots had significantly more roots than trees in the alfalfa or tall fescue plots. The 80 - to $120-\mathrm{cm}$ segment was beneath the alley management treatment, and trees in both vegetation-free treatments had significantly more roots than trees in the alfalfa or tall fescue plots.

Rooting differences occurred at all depths on the 1.2PF (Table 5). In the surface $20 \mathrm{~cm}$, the trees in the herbicide treatment had significantly more roots than trees in any other treatment. Trees grown in clean cultivation had significantly more roots than trees in all vegetative covers. Although this difference was not present closer to the tree on the WPF, it appeared that mechanical cultiva-

Table 3. Total number of peach tree roots per square meter at a depth of 0 to $20 \mathrm{~cm}$ in relation to orchard floor management. Data are for the west profile-face (WPF) $0.6 \mathrm{~m}$ from the tree perpendicular to the tree row.

\begin{tabular}{|c|c|c|c|c|c|c|}
\hline \multirow[b]{2}{*}{$\begin{array}{l}\text { Depth } \\
\text { (cm) }\end{array}$} & \multicolumn{6}{|c|}{ Treatment } \\
\hline & Herbicide & $\begin{array}{c}\text { Clean } \\
\text { cultivation }\end{array}$ & $\begin{array}{l}\text { Kentucky } \\
\text { bluegrass }\end{array}$ & $\begin{array}{l}\text { Chewings } \\
\text { fescue }\end{array}$ & Alfalfa & $\begin{array}{c}\text { Tall } \\
\text { fescue }\end{array}$ \\
\hline \multicolumn{7}{|c|}{ - Roots $/ m^{2}$} \\
\hline $0-20$ & $436 a^{2}$ & $437 \mathrm{a}$ & $422 \mathrm{a}$ & $364 \mathrm{ab}$ & $252 \mathrm{~b}$ & $280 \mathrm{~b}$ \\
\hline $20-40$ & 228 a & $149 \mathrm{a}$ & $191 \mathrm{a}$ & $178 \mathrm{a}$ & $156 \mathrm{a}$ & $120 \mathrm{a}$ \\
\hline $40-60$ & $109 \mathrm{a}$ & $99 \mathrm{a}$ & $91 \mathrm{a}$ & $113 \mathrm{a}$ & $88 \mathrm{a}$ & $68 \mathrm{a}$ \\
\hline $60-80$ & $108 \mathrm{a}$ & $65 \mathrm{a}$ & $58 \mathrm{a}$ & $63 \mathrm{a}$ & $42 \mathrm{a}$ & $38 \mathrm{a}$ \\
\hline $80-100$ & $77 \mathrm{a}$ & $55 \mathrm{a}$ & $24 \mathrm{a}$ & $51 \mathrm{a}$ & $35 \mathrm{a}$ & $36 \mathrm{a}$ \\
\hline
\end{tabular}

$\overline{{ }^{z} \text { Means separated within rows by Duncan's multiple range test }(P \leq 0.05)}$. Data shown are the means of four observations.
Table 4. Total number of peach tree roots per square meter in the surface $20 \mathrm{~cm}$ of the soil profile as affected by orchard floor management. Data are presented for $40-\mathrm{cm}$ columns on the west profile-face (WPF) 0.6 $\mathrm{m}$ from the tree perpendicular to the tree row.

\begin{tabular}{|c|c|c|c|c|c|c|}
\hline \multirow{2}{*}{$\begin{array}{l}\text { Distance } \\
\text { from tree } \\
\text { row }(\mathrm{cm})\end{array}$} & \multicolumn{6}{|c|}{ Treatment } \\
\hline & Herbicide & $\begin{array}{c}\text { Clean } \\
\text { cultivation }\end{array}$ & $\begin{array}{l}\text { Kentucky } \\
\text { bluegrass }\end{array}$ & $\begin{array}{l}\text { Chewings } \\
\text { fescue }\end{array}$ & Alfalfa & $\begin{array}{c}\text { Tall } \\
\text { fescue }\end{array}$ \\
\hline & \multicolumn{6}{|c|}{ Roots $/ m^{2}$} \\
\hline $0-40$ & $597 a^{z}$ & $505 \mathrm{a}$ & $688 \mathrm{a}$ & 589 a & $389 a$ & $478 \mathrm{a}$ \\
\hline $40-80$ & $441 \mathrm{ab}$ & $496 a$ & $428 a b$ & $331 \mathrm{bc}$ & $269 c$ & $293 c$ \\
\hline $80-120$ & $271 \mathrm{a}$ & $309 a$ & $150 \mathrm{ab}$ & $171 a b$ & $97 \mathrm{~b}$ & $71 \mathrm{~b}$ \\
\hline
\end{tabular}

${ }^{\text {z} M e a n s ~ s e p a r a t e d ~ w i t h i n ~ r o w s ~ b y ~ D u n c a n ' s ~ m u l t i p l e ~ r a n g e ~ t e s t ~}(P \leq 0.05)$. Data shown are means of four observations.

tion reduced the number of roots in the surface $20 \mathrm{~cm}$ of the cleancultivated plots compared to trees in the herbicide-treated plots. Beckenbach and Gourley (1932) and Cockroft and Wallbrink (1966), and others, have also reported that mechanical cultivation eliminated roots close to the soil surface. While cultivation reduced the number of roots in this study, trees in this treatment contained more roots than trees in the vegetative covers. At the 20to $40-\mathrm{cm}$ depth, the trees in the herbicide treatment had significantly more roots than trees with chewings fescue, alfalfa, and tall fescue. Trees in the vegetation-free plots tended to have the most roots at all depths.

To evaluate the effect of the orchard floor management treatments on tree rooting, the data from the $1.2 \mathrm{PF}$ profile must be examined. The number of tree roots on the $1.2 \mathrm{PF}$ were affected by the vegetative cover without interaction with a herbicide strip. Trees grown with either vegetation-free cover had more roots on the $1.2 \mathrm{PF}$ than those with any of the vegetative covers (Table I). Also, the vegetative covers used in this study provided unequal interference with tree root growth. Trees grown in tall fescue had fewer roots than trees in the Kentucky bluegrass or alfalfa covers (Table 1). This finding was also supported by differences in the number of roots at several depth increments (Table 2) when trees grown in tall fescue were compared to trees grown in Kentucky bluegrass.

The number of peach tree roots decreased with depth within all treatments. The mean slopes of the square root of the number of roots on the WPF ranged from -1.81 to -2.61 for the orchard floor management treatments, with standard deviations ranging from 0.20 to 0.87 . These slopes on the $1.2 \mathrm{PF}$ ranged from -0.73 to -1.483 for the orchard floor management treatments, with standard deviations ranging from 0.26 to 0.61 . This result indicates that the number of roots decreased uniformly with depth for each orchard

Table 5. Total number of peach tree roots per square meter at $20-\mathrm{cm}$ depth increments as affected by orchard floor management. Data are presented for the 1.2-m (1.2PF) profile-face parallel to the tree row.

\begin{tabular}{lcccccc}
\hline \hline & \multicolumn{5}{c}{ Treatment } \\
\cline { 2 - 7 } $\begin{array}{l}\text { Depth } \\
(\mathrm{cm})\end{array}$ & Herbicide & $\begin{array}{c}\text { Clean } \\
\text { cultivation }\end{array}$ & $\begin{array}{c}\text { Kentucky } \\
\text { bluegrass }\end{array}$ & $\begin{array}{c}\text { Chewings } \\
\text { fescue }\end{array}$ & $\begin{array}{c}\text { Tall } \\
\text { Alfalfa } \\
\text { fescue }\end{array}$ \\
\hline \multicolumn{7}{c}{ Roots $/ m^{2}$} \\
$0-20$ & $418 \mathrm{a}^{\mathrm{z}}$ & $293 \mathrm{~b}$ & $185 \mathrm{c}$ & $150 \mathrm{c}$ & $129 \mathrm{c}$ & $92 \mathrm{c}$ \\
$20-40$ & $212 \mathrm{a}$ & $162 \mathrm{ab}$ & $154 \mathrm{ab}$ & $114 \mathrm{bc}$ & $119 \mathrm{bc}$ & $62 \mathrm{c}$ \\
$40-60$ & $85 \mathrm{ab}$ & $138 \mathrm{a}$ & $112 \mathrm{ab}$ & $64 \mathrm{bc}$ & $92 \mathrm{ab}$ & $22 \mathrm{c}$ \\
$60-80$ & $85 \mathrm{ab}$ & $118 \mathrm{a}$ & $55 \mathrm{bc}$ & $29 \mathrm{c}$ & $52 \mathrm{~b}$ & $13 \mathrm{c}$ \\
$80-100$ & $69 \mathrm{ab}$ & $85 \mathrm{a}$ & $20 \mathrm{~b}$ & $19 \mathrm{~b}$ & $35 \mathrm{~b}$ & $16 \mathrm{~b}$
\end{tabular}

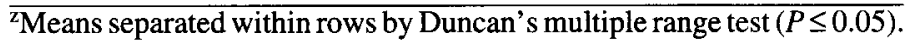
Data shown are means of four observations. 

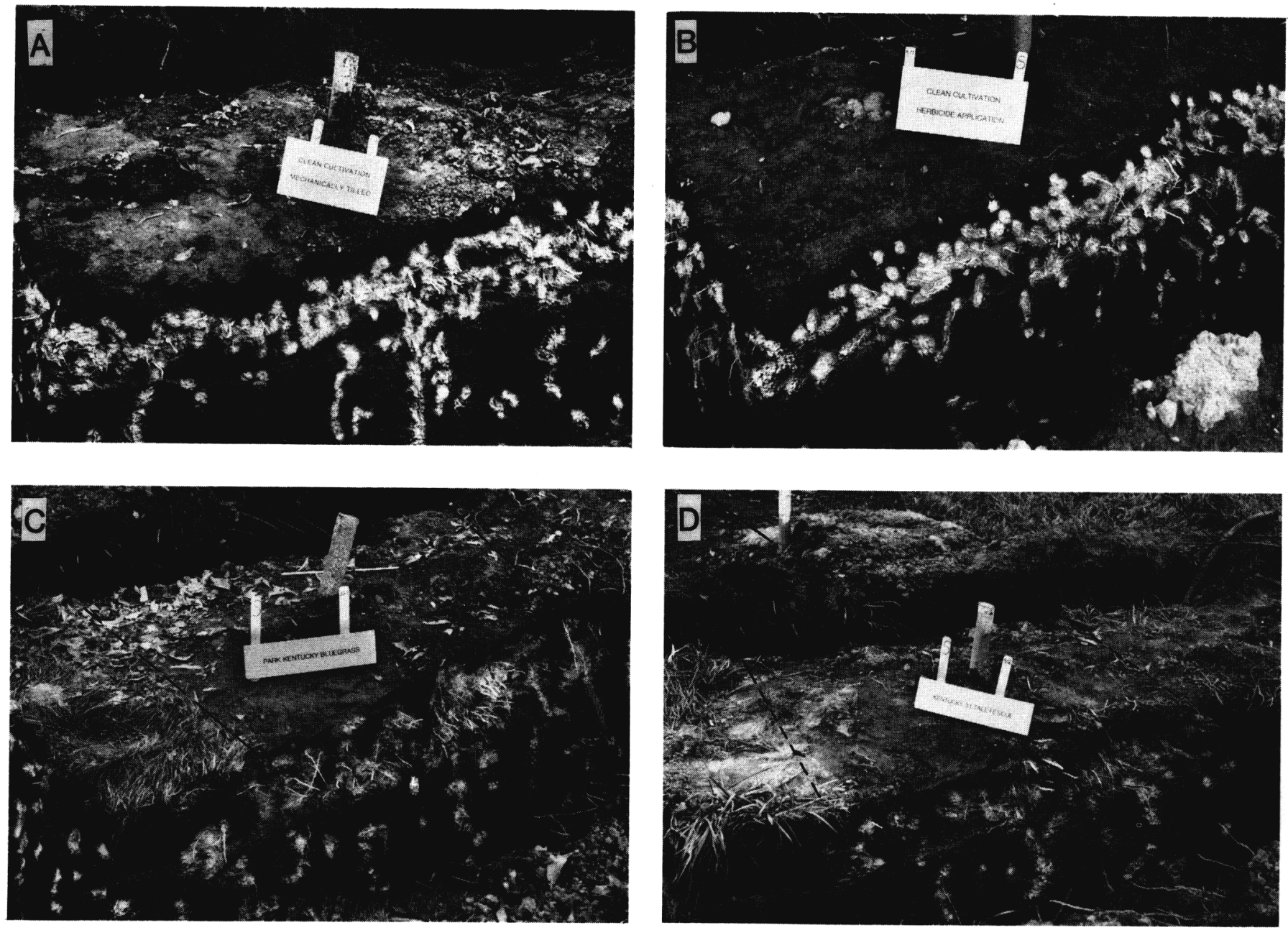

Fig. 2. The effect of orchard floor management on peach tree root distribution. Peach roots sprayed with white latex paint to highlight root distribution. Arrows indicate row orientation and dashed line indicates sod/herbicide strip interface. (A) Clean cultivation; (B) complete vegetation controlled with herbicide; (C) 'Park' Kentucky bluegrass; (D) 'Kentucky 31' tall fescue.

floor management treatment. The decrease in fruit tree rooting with depth has also been reported in peach by Cowart (1938) and Lyons and Krezdorn (1962). Beckenbach and Gourley (1932) reported that apple root concentrations decreased with depth.

There were no significant treatment differences in the slopes of the square root of the number of roots for either the WPF or the 1.2PF (data not shown). The decrease in the number of roots with depth did not differ between the orchard floor management treatments, indicating that the number of roots decreased with depth regardless of the orchard floor cover and that trees grown in vegetative covers do not root deeper than those in vegetation-free soil. Cockroft and Wallbrink (1966) also reported that orchard floor management treatments did not result in trees rooting deeper.

The reduction in the number of roots of trees in the vegetative covers compared to the vegetation-free plots suggests interference. Interference is the effect on plant growth of one plant induced by another (Radosevich and Holt, 1984); it can either promote or inhibit plant growth. The mechanisms by which interference may affect plant growth are numerous. In this study, two probable effects of inhibitory interference were competition and allelopathy, although the issue was not studied. Competition for nutrients and water would be a direct effect, and allelopathy, the inhibition of growth of one plant due to substances released from another (Putnam and Tang, 1986), would be an indirect effect. Further study is needed to determine if interference is affecting peach tree rooting under vegetative covers.

The orchard floor management treatments evaluated affected peach root distribution. The very vigorous and deeper rooting covers of ' $\mathrm{K}-31$ ' tall fescue and 'Peak' alfalfa resulted in fewer tree roots both vertically and horizontally than the vegetation-free treatments. More rooting appeared to have occurred in the relatively low vigor cover of 'Park' Kentucky bluegrass than in 'K-31' tall fescue (Fig. 2). Treatments eliminating all orchard floor vegetation facilitated production of the highest number of tree roots, horizontally and vertically.

Clean cultivation eliminated surface-rooting of peach trees. However, orchard floor management practices with a herbicide strip in the tree row promoted surface-rooting. The selection of vegetative covers for the orchard alleyway is a crucial decision and the least-competitive vegetative covers that would minimize interference with peach tree growth and rooting should be used.

\section{Literature Cited}

Atkinson, D. and G.C. White. 1976. Soil management with herbicidesthe response of soils and plants. Proc. 1976 Brit. Crop Prot. Cont.Weeds 3:873-884.

Atkinson, D., G.C. White, E.R. Mercer, M.G. Johnson, and D. Mattam, 1977. The distribution of roots and the uptake of nitrogen by established apple trees grown in grass with herbicide strips. Rpt. E. Mailing Res Sta. for 1976. p. 183-185.

Atkinson, D. 1980. The distribution and effectiveness of the roots of tree 
crops. Hort. Rev. 2:424-490.

Beckenbach, J. and J.H. Gourley. 1932. Some effects of different cultural practices upon root distribution of apple trees. Proc. Amer. Soc. Hort. Sci. 29:202-204.

Beukes, D.J. 1984. Apple root distribution as effected by irrigation at different soil water levels on two soil types. J. Amer. Soc. Hort. Sci. 109:723-728.

Blake, G.D. 1965. Bulk density. Agronomy 9. Part I. p.374-377.

Bohm, W. 1979. Methods of studying root systems. Springer-Verlag, Berlin.

Boswell, S.B., C.D. McCarty, and L.N. Lewis. 1975. Tree density affects large-root distribution of 'Washington' navel orange trees. HortScience 10:593-595.

Castle, W.S. 1980. Fibrous root distribution of 'Pineapple' orange trees on rough lemon rootstock at three tree spacings. J. Amer. Soc. Hort. Sci. 105:478-480.

Cockroft, B. and J.C. Wallbrink. 1966. Root distribution of orchard trees. Austral. J. Agr. Res. 17:49-54.

Cowart, F.F. 1938. Root distribution and root and top growth of young peach trees. Proc. Amer. Soc. Hort. Sci. 36:145-147.

Cripps, J.E. 1971. The influence of soil moisture on apple root growth and root:shoot ratios. J. Hort. Sci. 46:121-130.

Glenn, D.M. and W.V. Welker. 1989. Peach root development and tree hydraulic resistance under tall fescue sod. HortScience 24: 117-119.

Haynes, R.J. 1980. Influence of soil management practice on the orchard agro-ecosystem. Agro-ecosystems 6:3-32.

Hogue, E.J. and G.H. Nielsen. 1987. Orchard floor vegetation management. Hort. Rev.. 9:377-430.

Layne, R.E.C., C.S. Tan and R.L. Perry. 1986. Characterization of peach roots in fox sand as influenced by sprinkler irrigation and tree density. J. Amer. Soc. Hort. Sci. 111:670-677.

Lyons, C.G., Jr., and A.H. Krezdorn. 1962. Distribution of peach roots in Lakeland fine sand and the influence of fertility levels. Proc. Florida State Hort. Soc. 75:371-377.

Perry, R.L., S.D. Lyda, and H.H. Bowen. 1983. Root distribution of four Vitis cultivars. Plant \& Soil 71:63-74.

Putnam, A.R. and C.S. Tang. 1986. The science of allelopathy. Wiley, New York.

Radosevich, S.R. and J.S. Holt. 1984. Weed ecology: Implications for vegetation management. Wiley, New York.

Richards, D. and B. Cockroft. 1975. The effect of soil water on root production of peach trees in summer. Austral. J. Agr. Res. 26: 173-180. 